\title{
Extending Arenes via C-H Activation with Rhodium
}

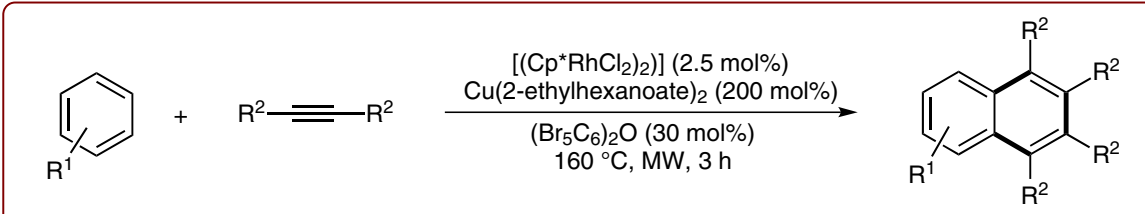

Selected examples:<smiles>Brc1c(Br)c(Br)c2ccccc2c1Br</smiles>

$80 \%$ yield

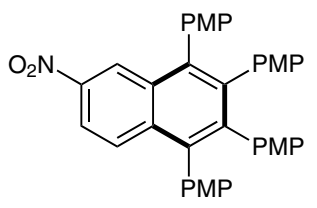

$48 \%$ yield<smiles>CC(C)Cc1c(C(C)(C)C)c(CC(C)C)c2cc3ccccc3cc2c1CC(C)C</smiles>

$60 \%$ yield<smiles>O=[N+]([O-])c1ccc2c(Br)c(Br)c(Br)c(Br)c2c1</smiles>

$63 \%$ yield<smiles>COCc1c(COC)c(COC)c2cc(C(F)(F)F)ccc2c1COC</smiles>

$51 \%$ yield<smiles>CC(C)Cc1c(C(C)C)c(CC(=O)c2ccccc2)c2cc3sc4ccccc4c3cc2c1Cc1ccccc1</smiles>

$65 \%$ yield<smiles>CCC(C)c1c(CC(C)C)c(CC(C)C)c2ccc(OC)cc2c1CC(C)C</smiles>

$44 \%$ yield

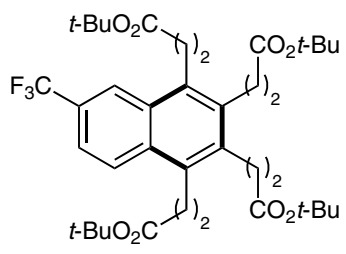

$40 \%$ yield

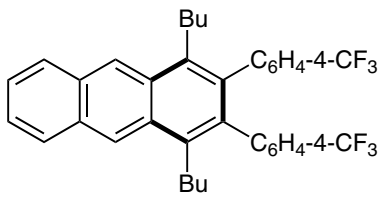

$57 \%$ yield
Significance: Extending the conjugation length of arenes is of great interest to the materials chemistry community due to the impartation of new electrical and photophysical properties. The previously reported method for rhodium-catalyzed arene homologation was achieved with a boronic acid functionalized substrates (J. Org. Chem. 2011, 76, 2867); in contrast, Pham and Cramer report a C$\mathrm{H}$ functionalization to achieve the same transformation.

sYNFACTS Contributors: Timothy M. Swager, John B. Goods Synfacts 2014, 10(5), 0473 Published online: 17.04.2014 DOI: 10.1055/s-0033-1341163; Reg-No.: S02614SF

\section{Gategory}

Synthesis of

Materials and

Unnatural Products

\section{Key words}

polyaromatic hydrocarbons

rhodium

C-H functionalization
Comment: While dibutyl alkynes were used most prominently in this paper, the authors were also able to demonstrate that other alkynes, including those bearing aryl groups, could be incorporated. A proposed mechanism for the transformation is included in the paper. 